ENTREPRENEURSHIP AND SUSTAINABILITY ISSUES

ISSN 2345-0282 (online) http://jssidoi.org/jesi/ 2021 Volume 9 Number 1 (September)

http://doi.org/10.9770/jesi.2021.9.1(2)

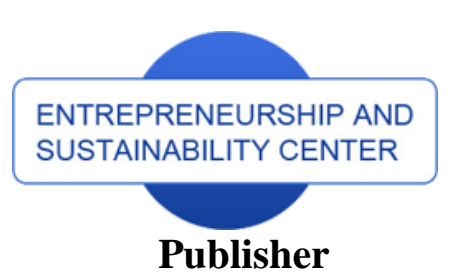

http://jssidoi.org/esc/home

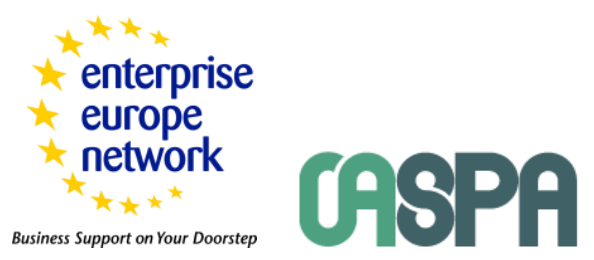

Business Support on Your Doorstep enterprise

europe

network

\title{
MOTIVATIONAL FACTORS AT WORK OF E-COMMERCE AND E-BUSINESS EMPLOYEES. WHAT IS THE DIFFERENCE BETWEEN GENDERS?*
}

\author{
Pavel Ziaran ${ }^{1}$, Richard Fedorko ${ }^{2}$, Beata Gavurova ${ }^{3}$, Radovan Bacik ${ }^{4}$ \\ 1,2,4 University of Prešov, Faculty of Management, Konštantínova 16, 08001 Prešov, Slovakia \\ ${ }^{3}$ Technical University of Košice, Faculty of Mining, Ecology, Process Control and Geotechnologies, Letná 9 , \\ 04200 Košice, Slovakia
}

E-mails: ${ }^{1}$ pavel.ziaran@unipo.sk; ${ }^{2}$ richard.fedorko@unipo.sk; ${ }^{3}$ beata.gavurova@tuke.sk; ${ }^{4}$ radovan.bacik@unipo.sk

Received 12 February 2021; accepted 25 May 2021; published 30 September 2021

\begin{abstract}
The objective of this research is to understand gender differences in motivational drivers at workplace, with a focus on people with working experiences in the field of e-commerce and e-business. Special attention is devoted to the preference of the competitive and cooperative behaviour. We examined gender differences in the preference of eight motivational drivers on a sample of $\mathrm{N}=429(41 \%$ females). Results showed that males ranked higher in motivation by professional challenge, preference of competitive settings and opportunities to develop. Females scored higher in the motivation by social support and physical working environment. Interestingly, there were found no gender differences in preference of financial reward and recognition, what supports the thesis of equal pay and equal treatment policies. The most pronounced gender differences occurred in the preference of competitive vs. cooperative behaviour. Males have significantly higher preference of competition when compared to females and vice-versa. In the analytical quadrant of motivation by high competition and low cooperation there was $35 \%$ of males and $16 \%$ of females. In the opposite quadrant of motivation by low competition and high cooperation there were $24 \%$ of males vs. $45 \%$ of females. Results have interesting implications for management of human resources and gender-based talent management.
\end{abstract}

Keywords: work motivation; gender differences; HR management; cooperative and competitive behavior

Reference to this paper should be made as follows: Ziaran, P., Fedorko, R., Gavurova, B., Bacik, R. 2021. Motivational factors at work of e-commerce and e-business employees. What is the difference between genders?. Entrepreneurship and Sustainability Issues, 9(1), 23-36. http://doi.org/10.9770/jesi.2021.9.1(2)

JEL Classifications: M12

Additional disciplines Personnel Management

\footnotetext{
* This article is one of the partial outputs under the scientific research grant VEGA 1/0694/20 - Relational marketing research - the perception of e-commerce aspects and its impact on purchasing behaviour and consumer preferences and VEGA 1/0609/19 - Research on the development of electronic and mobile commerce in the aspect of the impact of modern technologies and mobile communication platforms on consumer behaviour and consumer preferences
} 


\section{ENTREPRENEURSHIP AND SUSTAINABILITY ISSUES}

ISSN 2345-0282 (online) http://jssidoi.org/jesi/

2021 Volume 9 Number 1 (September)

http://doi.org/10.9770/jesi.2021.9.1(2)

\section{Introduction}

In today's corporations, the key pillar of the corporate success is people with appropriate motivation. The objective of this paper is to analyze gender differences in the motivational drivers. The results might be particularly interesting for better and more efficient design of motivational systems and talent management across organizations. Motivation can be defined as a theoretical construct explaining behaviour, notably the reasons for human actions. Motivation represents a stimulus to behavioral tendency or behaviour, on the repetitive basis (Elliot and Covington 2001). Work motivation may contain several dimensions, or attitude-based motives. There is a wider spectrum of theories explaining the nature of motivational dimensions and aspects. Pardee (1990) highlighted four theories that he calls "classics": (1) Maslow's hierarchy of needs, (2) Herzberg's dual-factor theory of two factors, (3) McGregor's Theory XY and (4) McClelland's motivational theory (achievement, affiliation, power).

Some motivational drivers have neuropsychological correlates, both functional and morphological. Lee et al. (2012) demonstrated the differences between brain activity during intrinsic and extrinsic motivation. Takeuchi et al. (2014) found the correlates in the morphology and density of the grey matter in the respective areas of the brain, corresponding to the differences in the preferred type of motivation: achievement based on self-realization versus motivation on the social competition.

Biological determination of motivational processes and consequent behavioral tendencies advocates the idea to perceive motivational driver as a time-consistent personality trait. From the point of view of HR diagnostics, a motivational factor which is stable and consistent in time can be understood as a factor determining personality. Hence, this type of motivational factors can be looked upon as personality traits and can serve as a predictor of job performance and professional success.

Through the prism of the literature review, the objective of this research it to find out, whether there is a statistically significant difference between men and women with respect to the selected motivational drivers (professional challenge, financial reward, recognition of performance, motivation by competition, motivation by cooperation, social support, physical working environment and development opportunities).

We can formulate three research questions as follows:

1. Which motivational driver are more preferred by males (RQ1).

2. Which motivational driver are more preferred by females (RQ2).

3. Which motivational drivers do not generate significant differences between genders, gender-neutral (RQ3).

Special attention is devoted to the gender differences in the preference of competitive and cooperative organizational settings. The findings are supposed to provide interesting implication for the design of motivational systems in the talent-oriented organizations.

\section{Theoretical background}

Research in motivation at workplace is quite numerous. There are two basic approaches how to measure motivational drivers. First, some authors analyse how respondents rank individual motivational factors, and subsequently compare differences among groups, based on age, gender and job type, e.g. (Kovach 1987, Elizur 1994, Lorincová et al. 2019). Secondly, some researchers analyse the importance of the work values in relation to the overall work satisfaction e.g. (Eskildsen, Kristensen, Westlund 2004, García-Bernal et al. 2005) or happiness (Furnham et al. 2005). We use the first approach, based on the direct indication (ranking) of preferences for individual motivational factors. Furthermore, in this paper we focus on the selected motivational drivers, which might be used by the employers in almost all types of jobs: financial reward and recognition, personal 


\section{ENTREPRENEURSHIP AND SUSTAINABILITY ISSUES}

ISSN 2345-0282 (online) http://jssidoi.org/jesi/

2021 Volume 9 Number 1 (September)

http://doi.org/10.9770/jesi.2021.9.1(2)

development and professional challenge, social support and physical work environment. Special focus is devoted to the competitive and cooperative behavioural preference.

\section{Financial rewards and verbal recognition of performance}

There are two forms of appraisals: the ones with the link to the financial outcomes and those without monetary consequences (Kampkötter 2017). Monetary award belongs historically among the most straightforward motivational driver, and one of the most considered since the beginning of the management history (Bernard, Walsh, Mills 2005). However, nowadays, the companies offer such a wide spectrum of motivational drivers as personal development, interesting and meaningful work, quality of personal interactions that the financial compensation become less important (Seiler et al. 2012).

\section{Financial reward}

Buelens and Van den Broeck (2007) found that men are significantly more motivated by the financial reward. Elizur (1994) found that men ranked higher values such as financial reward, influence, independence, and responsibility. Major and Konar (1984) found females' expectations on the financial remuneration at the beginning and at the top of the career significantly lower, when compared to man, but he adds, this might be due the different expected career paths. Interestingly, Smith and Tolbert (2019) point out that motivation by financial reward in the segment of individual entrepreneurs, however, can have different effects on the duration the small business, based on the race and gender.

Recognition for work

Verbal appraisal for a quality performance at work belongs among the most efficient tools in HR management (Judge, Ferris 1993). It serves as a form of a feedback, that's why it is important to comply with the aspect of fairness. At the same time, it is an important vehicle of social relation, even in formal settings. Kovach (1987) found women to be more sensitive to the appreciation at work, when compared to men. Gunkel et al. (2007) found no significant differences when it comes to the performance rewards and similarly, Lorincová et al. (2019) did not find statistically significant differences between genders in the formal appraisal related factors, fair appraisal system and information about the performance results. In the cross-cultural study by Elizur (1994), females ranked recognition higher in the group of Dutch participants. In the Hungarian group men ranked recognition slightly higher, however the difference was small.

We formulate hypothesis as follows:

Hypothesis 1a: Males rank the financial reward significantly higher than females

Hypothesis 1b: Males rank the recognition of performance significantly higher than females

\section{Personal development and professional challenge}

Personal development denotes a process where a person, in the frame of working life acquires a wide spectrum of skills and knowledge relied to the self-actualization and self-fulfillment, increasing the self-perceived value of the person. According to García-Bernal et al. (2005), personal development on the job (including various skills and professional enhancements) explains the largest part of variability in job-satisfaction when compared to other types of motivational drivers.

\section{Professional challenge}

Professional challenge could be understood as a tendency to develop one owns abilities, however in the course of specific, goal-oriented actions. Žiaran et al. (2016) showed that professional challenge is related with professional personality traits as ambitions, competitiveness, result orientation and inventiveness. As regards the professional challenge, it is relied with the readiness to take the risk. Research shows that this tendency might be biologically determined. Alarcón et al. (2007) found that risky task associated with money gains are more attractive for males and generate a more robust reaction in brain activity. 


\section{ENTREPRENEURSHIP AND SUSTAINABILITY ISSUES}

ISSN 2345-0282 (online) http://jssidoi.org/jesi/

2021 Volume 9 Number 1 (September)

http://doi.org/10.9770/jesi.2021.9.1(2)

Opportunity of personal development

Elizur (1994) found, Hungarian women attributed a distinctly higher importance to the personal growth as compared to men, whereas in the Dutch sample personal growth was slightly more appreciated by the males. Interestingly, Hungarian group on average ranked the personal growth much higher when compared to the Dutch participants. Similarly, at the level of the whole sample average, Arnanie-Kepuladze (2010) found the opportunity for advancement more accentuated by females than by males, however in some sectors males had a somewhat more pronounced preference. In the study made by Lorincová et al. (2019) females ranked personal growth higher than males, however the difference in total value of ranking was minuscule and there was not a statistically significant difference in the preference of self-actualization among genders.

We formulate hypothesis as follows:

Hypothesis 2a: Males rank the professional challenge significantly higher than females

Hypothesis $2 b$ : Females rank the opportunity of personal development significantly higher than males

\section{Social relations and support and working environment}

Social support at work

Good social relations and social support is undoubtedly an important aspect of well-being at work. Social support (from both, supervisor and co-workers) helps to mitigate the adverse effects of job stress and to increase the level of work performance (Sargent, Terry 2000). Social support also augments intrinsic working motivation (Van Yperen 2003).

Research shows that women perceive a higher working motivation in the frame of supportive environment (Buelens, Van den Broeck 2007). According to Lorincová et al. (2019), atmosphere at the workplace is more important for females as well as a good work team and communication at workplace. In the cross-cultural research by Elizur (1994) both, Hungarian and Dutch females ranked the importance of good relations with coworkers dramatically higher, when compared to males.

Quality of working environment (physical)

Workspace and its physical arrangement might affect employees' job performance and satisfaction (Vischer 2007). Knight and Haslam (2010) showed that nicely decorated offices with plants and pieces of arts improve productivity and well-being. When employees can contribute themselves to the decoration, the positive effects on work motivation is accentuated. Research showed that the quality of the work environment is more important for women (Lorincová et al. 2019, Elizur 1994).

We formulate hypothesis as follows:

Hypothesis 3a: Females rank the social support at work significantly higher than males

Hypothesis 3b: Females rank the quality of working environment significantly higher than males

\section{Competitive vs. cooperative settings at work}

Gender differences in the preference of the competitive setting by males and cooperative one by females manifest already in the early stage of human development and are observable since the age of three (Knight, Chao 1989, Sutter, Rützler 2010). In the series of behavioural experiments, Vugt et al. (2007) showed that males' tendency to contribute to a group was much higher when the group was competing with another one. Niederle and Vesterlund (2007), in an experimental environment, found that males-to-females proportion of preference of the competitive to cooperative settings was $73 \%$ to $35 \%$. Research showed that women perform better in the cooperative settings as when to compared to the competitive one, should it be in cognitive tasks (Gneezy, Niederle, Rustichini 2003) or in learning assignments (Rodger, Murray, Cummings 2007).

Hypothesis 4a: Males rank the competitive settings at work significantly higher than females

Hypothesis 4b: Females rank the cooperative settings at work significantly higher than males 


\section{ENTREPRENEURSHIP AND SUSTAINABILITY ISSUES}

ISSN 2345-0282 (online) http://jssidoi.org/jesi/

2021 Volume 9 Number 1 (September)

http://doi.org/10.9770/jesi.2021.9.1(2)

\section{Other factors than gender}

Differences in gender values might be also related to the specific cultural environments in the respective countries. Research by Hofstede (2001) brought the notion of the cultural predetermination of values in the organizations around the globes. Yamauchi et al. (1994) carried out cross-cultural studies of gender differences in the European and oriental culture with the regard to seven work motivations and attitudes (work ethic, mastery, competitiveness, savings, achievement motivation, valuation for money, and achievement via conformity). The findings support the thesis that motivational drivers might correspond to cultural differences.

Rowe and Snizek (1995) in their extensive studies across the spectrum of occupational classifications suggest that type of work, education or age is a stronger predictor of work values than gender. Both genders rank the work values as feeling of accomplishment, high income, opportunity for advancement in the same order of preference. As one of explanation is the fact, that social roles for both genders are assimilating. Furnham et al. (2005) in his study on motivational and personality traits, on British and Greek employees, found that the only significant difference on matter of gender was that women ranked higher the autonomy, while other factors were not gender related.

Hauret and Williams (2017) analysed data for several European countries (European Social Survey) and came to conclusion that gender-related job satisfaction and work values are more related to the job specific characteristics. Kaufman and Fetters (1980) enacted a study on a group of professional accountants working for the top international accounting firms. No significant differences were found between men and woman on any of the motivational variables. This might be due to the specific and highly determined nature of the job requirements, personality requirement, combined with the organizational environment and culture. In other words, it might be due to the fact that these companies systematically select personnel with strictly pre-defined motivational drivers, specific cognitive abilities and personality traits, all based on a specific competence model. Hence, the lack of gender differences in this type of organization could be regarded as a systemic exception.

\section{Methodology}

\section{Sample and procedure}

The sample is based on the adult, economically active population of the Czech Republic, having working experiences in the field of e-commerce and e-business, $\mathrm{N}=429$ (176 females, $41 \%$ ). Age range for males was 20 to 41 years (mean 35.3), for females 21 to 38 years (mean 29.3). The data were collected via online questionnaires (convenient sampling).

\section{Measurements and variables}

In the research, we use the motivational factors described in table 1. The questionnaires are based on the methodology of the company Cut-e (Cut-e $\mathrm{GmbH}, 2008)$. In the questionnaire, the structure of motivation is measured as a verbalized cognitive view or attitude towards the relevant aspect of work or professional context. The variables are constructed to assess the motivational factors, values and interests that are crucial to a person's suitability to work in a particular company, department or team, in terms of corporate culture. The questionnaire gathers motivational factors into three groups: rewards, development, relations and environment. We also included preference of competitive and cooperative organizational settings, as these might be the main determinants of organisational environment. 
Table 1 Verbal description of variables used

\section{Reward}

Financial reward - Prefers a performance-oriented or adequate pay; considers it important that extra work is rewarded financially; is motivated by financial incentives.

Recognition of performance -Would like to receive personal recognition for special achievements; considers it important that successful actions are acknowledged and also accordingly appreciated.

Development

Professional challenge - Prefers jobs which challenge individual abilities; would like to be able to utilize special knowledge or skills; prefers a working environment which requires constant learning and initiative for thinking things through.

Development opportunities - Considers it important that personal and career development is given enough latitude and would like to have enough opportunities to improve their professional skills.

\section{Relations and environment}

Social support - Considers important the atmosphere of mutual support and trust, harmonic and supportive relations at the workplace.

Working environment - Prefers well-arranged rooms and workstations; appreciates workplaces which are pleasant and functional.

\section{Competitive vs cooperative setting}

Motivation by competition -Is motivated by the presence of competitive environment, based on the social comparison of the working results and success.

Motivation by cooperation - Prefers a climate of cooperativeness; appreciates the willing support from others when this becomes necessary; would prefer that individuals put their own personal interests aside for the benefit of others

\section{Source: based on Cut-e Czech s. r. o(2015)}

The test results (ranging from 1 to 9) can be interpreted on the stanine nine-point scale, 1-3: below average, 4-6: average, 7-9: above average. Motivational questionnaires are an effective and valid selection method in HR because the structure of motivations and interests clearly and distinctly separate individuals to a large extent on a timely consistent basis. Table 2 provides an overview of the variables' basic values. Table 2 provides an overview of the variables (all values range from 1 to 9).

Table 2 Overview of the variables and their values

\begin{tabular}{lccc}
\hline & Mean & Median & $\begin{array}{c}\text { Std } \\
\text { Dev. }\end{array}$ \\
\hline Professional challenge & 3.41 & 3 & 1.80 \\
Motivated by the competition & 4.13 & 4 & 2.03 \\
Development opportunities & 4.68 & 5 & 2.00 \\
Recognition of performance & 5.05 & 5 & 1.90 \\
Motivated by cooperation & 5.29 & 5 & 1.89 \\
Need of support & 5.36 & 5 & 1.79 \\
Financial reward & 5.42 & 5 & 1.84 \\
Working environment & 6.23 & 6 & 1.75 \\
\hline
\end{tabular}

Source: own elaboration

\section{Data analysis}

We use the non-parametric Mann-Whitney $U$ test to identify the gender differences in the preference of motivational drivers, testing the hypothesis $\mathrm{H1a}-\mathrm{H} 4 \mathrm{~b}$ (chapter 4.1). Subsequently, we employ the correlations analysis (Spearman) to understand relations among the motivational drivers which appears to be gender neutral (chapter 4.2) and other drivers. Finally, by means of the Chi-quadrat and Fi-coefficient, we verify differences between the gender preferences of competitive and cooperative work settings (chapter 4.3). 


\section{Results}

\section{Gender differences in the motivational drivers}

This chapter brings the key results. We employed the Mann-Whitney U test (number of valid observations is 176 for females and 503 for males) to analyse the gender-based differences in the preference of motivational drivers (table 3).

Adjusted Z-score could be interpreted as the intensity of preference of the respective motivational drivers. Negative Z-score value indicate higher preference of males and, vice-versa, for females. P-value higher than 0.05 suggests there are no significant gender differences for the given motivational driver.

Motivational drivers are sorted according to the Z- score, what allows to discern intensity of gender differences. In the very right column (table 3 ), the denotations of hypothesis are attributed accordingly.

Table 3 Motivation - gender differences (Mann-Whitney U test), sorted by the value of Z (adjusted)

\begin{tabular}{|c|c|c|c|c|}
\hline & $\mathrm{U}$ & $\mathrm{Z}$ (adjusted) & $\begin{array}{c}\mathrm{p} \\
\text { values }\end{array}$ & Hypothesis \\
\hline \multicolumn{5}{|c|}{ Males - higher preference of motivational factors } \\
\hline Motivated by the competition & 15925 & -5.08 & 0.00 & $\mathrm{H} 4 \mathrm{a}$ \\
\hline Professional challenge & 19429 & -2.28 & 0.02 & $\mathrm{H} 2 \mathrm{~b}$ \\
\hline Development opportunities & 19486 & -2.23 & 0.03 & $\mathrm{H} 2 \mathrm{a}$ \\
\hline \multicolumn{5}{|c|}{ No significant difference between men and women } \\
\hline Financial reward & 21377 & -0.71 & 0.48 & H1a \\
\hline Recognition of performance & 22120 & -0.12 & 0.91 & $\mathrm{H} 1 \mathrm{~b}$ \\
\hline \multicolumn{5}{|c|}{ Females - higher preference of motivational factors } \\
\hline Social support & 19921 & 1.89 & 0.05 & $\mathrm{H} 3 \mathrm{a}$ \\
\hline Working environment & 17937 & 3.49 & 0.00 & $\mathrm{H} 3 \mathrm{~b}$ \\
\hline Motivated by cooperation & 16703 & 4.47 & 0.00 & $\mathrm{H} 4 \mathrm{~b}$ \\
\hline
\end{tabular}

According to the results of the Man-Whitney U test we can confirm the following alternative hypotheses (p-value $<0.05$ ): H2a (Males rank the professional challenge significantly higher than females), H3a (Females rank the social support at work significantly higher than males), H3b (Females rank the quality of working environment significantly higher than males), H4a (Males rank the competitive settings at work significantly higher than females), H4b (Females rank the cooperative settings at work significantly higher than males).

Hypothesis $\mathrm{H} 2 \mathrm{~b}$ (Females rank the opportunity of personal development significantly higher than males) was not confirmed, as our results show the opposite; since it was males who manifested statistically significant higher preference for this motivational driver (Z-adjusted is negative, $\mathrm{p}$-value $<0.05$ ).

Hypotheses H1a (Males rank the financial reward significantly higher than females) and H1b (Males rank the recognition of performance significantly higher than females) were not confirmed (p-value >0.05); we accept the null hypothesis, what suggests there is not a statistically significant difference between genders. 
For better clarity, we summarize the results also according to the research questions (RQ1 - RQ3) as follows. Motivational drivers can be divided into three groups:

- Motivational drivers with significantly higher preference by males (RQ1): motivation by competition, professional challenge and development opportunities.

- Motivational drivers with significantly higher preference by females (RQ2): social support, working environment (physical), motivation by cooperative organizational settings.

- Motivational drivers with no significant differences between genders, gender-neutral (RQ3): financial reward and recognition of performance.

It is interesting to note that the highest difference between males and females is in the motivation by competitive versus cooperative environment (table 3: Z-scores, -5.46 vs. 4.88).

\section{Nature of the gender-neutral motivational drivers (financial reward and recognition of performance)}

In this section we analyse the relations of gender-neutral motivational factors (financial reward and recognition of performance) with other motivational drivers; aiming to reveal the underlying psychological processes which shape the motivation at work. We employ the correlation analysis, using the non-parametric Spearman coefficients (tables 4 and 5).

\section{Financial reward}

As regards financial reward (table 4), the are two positive statistically significant relations, same for both genders: relations with the recognition for work performance $(\mathrm{r}=0.28$ for males, $\mathrm{r}=0.31$ for females, $\mathrm{p}<0.05)$ and personal development $(r=0.23$ for males, $r=0.24$ for females, $p<0.05)$. And there is negative correlation with the motivation by cooperation for both genders $(r=0.14$ for males, $r=0.22$ for females, $p<0.05)$.

Table 4 Correlations financial reward vs. other motivational drivers, separately for both genders

\begin{tabular}{lccl}
\hline & \multicolumn{3}{c}{ Financial reward } \\
& Males & Females & \\
\hline Recognition of performance & $0.28^{*}$ & $0.31^{*}$ & Recognition of performance \\
Pers. development & $0.23^{*}$ & $0.24^{*}$ & Pers. development \\
Working environment & 0.08 & 0.08 & Working environment \\
Motivation by competition & 0.06 & 0.04 & Motivation by competition \\
Social support & -0.02 & -0.05 & Social support \\
Professional challenge & -0.07 & -0.11 & Professional challenge \\
Motivation by cooperation & $-0.14 *$ & $-0.22 *$ & Motivation by cooperation \\
\hline Note: Motivational drivers are sorted by the correlation coefficient (Correlations, Spearman coefficients), *p<0.05 & Source: own elaboration
\end{tabular}

\section{Recognition for work performance}

When it comes to the recognition for work performance, two motivational drivers correlate positively in the same way for both genders: above mentioned financial reward and personal development $(r=0.18$ for males, $r=0.25$ for females, $\mathrm{p}<0.05$ ). The gender differences manifest for females in the form of a working environment preference (not significant for males, $r=0.24$ for females, $\mathrm{p}<0.05$ ); and for males in two aspects: positive preference of the competition and negative preference of cooperation $(r=0.9, r=-0.13, p<0.05)$. 
ENTREPRENEURSHIP AND SUSTAINABILITY ISSUES

ISSN 2345-0282 (online) http://jssidoi.org/jesi/ 2021 Volume 9 Number 1 (September) http://doi.org/10.9770/jesi.2021.9.1(2)

Table 5 Correlations recognition of performance vs. other motivational drivers, separately for both genders

\begin{tabular}{lccl}
\hline \multicolumn{4}{c}{ Recognition for work performance } \\
& Males & Females & \\
\hline Financial reward & $0.28^{*}$ & $0.31^{*}$ & Financial reward \\
Pers. development & $0.18^{*}$ & $0.25^{*}$ & Pers. development \\
Motivation by competition & $0.13^{*}$ & $0.24^{*}$ & Working environment \\
Working environment & 0.09 & 0.11 & Motivation by competition \\
Social support & 0.02 & 0.08 & Social support \\
Professional challenge & -0.05 & 0.03 & Professional challenge \\
Motivation by cooperation & $-0.13^{*}$ & -0.10 & Motivation by cooperation \\
\hline Note: Motivational drivers are sorted by the correlation coefficient (Correlations, Spearman coefficients), ${ }^{*} p<0.05$ & \multicolumn{4}{c}{}
\end{tabular}

Distribution of genders in the matrix cooperative vs. competitive settings

In this section we compare the distribution of genders in the matrix of four quadrants, based on the competitive vs. cooperative motivation. Both scales are divided by median to the high and the low sections (table 6).

Table 6 Distribution of genders into the matrix of four quadrants: cooperative vs. competitive motivation (high, low), by median

\begin{tabular}{|c|c|c|c|}
\hline & & \multicolumn{2}{|c|}{ Motivation by cooperation } \\
\hline & & Low & High \\
\hline $\begin{array}{l}\text { Motivation by } \\
\text { competition }\end{array}$ & $\begin{array}{l}\text { High } \\
\text { Low }\end{array}$ & $\begin{array}{l}2 \\
\text { Males: } 35 \% \\
\text { Females: } 16 \% \\
1 \\
\text { Males: } 26 \% \\
\text { Females: } 27 \%\end{array}$ & $\begin{array}{l}4 \\
\text { Males: } 15 \% \\
\text { Females: } 11 \% \\
3 \\
\text { Males: } 24 \% \\
\text { Females: } 45 \%\end{array}$ \\
\hline
\end{tabular}

Quadrant no. 2 "high competition and low cooperation" clearly attracts higher proportion of males (males: $35 \%$, females: $16 \%$ ), whereas the quadrant no. 3 shows higher proportion of females (males: $24 \%$, females: $45 \%$ ). Difference in gender distribution between the two quadrants "high competition and low cooperation" vs "high cooperation and low competition" is statistically significant (Chi-square $=31,536, \mathrm{df}=2, \mathrm{p}<0.001$ ), and the gender distribution between the two quadrants, expressed by Fí coefficient $=0.277$, shows medium size effect. Interestingly, quadrant no. 4 "high cooperation and high competition" and quadrant no. 1 "low cooperation and low competition" do not manifest significant differences in gender distribution.

\section{Discussion}

\section{Gender-neutral motivational drivers}

Results of the Mann-Whitney U test showed that financial reward and recognition do not generate statistically significant difference in preference by genders (table 3). Hence, here, we confirmed the thesis of gender neutrality in line with Gunkel et al. (2007) and Arnania-Kepuladze (2010). The fact, that men and women have equal motivational preferences of the financial reward and recognition of work represent a strong argument supporting the initiative of the European Commission within the framework of gender equality and equal pay (European Commission 2018).

Interestingly, for both genders financial reward relates with all other motivational aspect in the same way and similar intensity, as measured by the correlation coefficients (table 4). Financial reward for both genders relates positively with recognition for work and personal development and negatively with motivation by cooperation. 


\section{ENTREPRENEURSHIP AND SUSTAINABILITY ISSUES}

ISSN 2345-0282 (online) http://jssidoi.org/jesi/

2021 Volume 9 Number 1 (September)

http://doi.org/10.9770/jesi.2021.9.1(2)

We observe that the motivational aspects related to the financial reward do not constitute gender differences, what justifies the thesis of the equal pay, not only as a matter of ethical principles but as well as from the psychological point of view.

On the other the recognition for working performance generates gender differences. For males, recognition for work associates positively with motivation by competition and negatively with motivation by cooperation. For females, recognition relates with working environment (besides financial motivation and personal development). These findings might be interpreted as a different psychological perception of the recognition by both genders.

\section{Gender based differences in motivation drivers}

Opportunities for personal development (table 3) are slightly more important for males, what does not correspond to the findings of other authors (Elizur 1994, Arnanie-Kepuladze 2010, Lorincová et al. 2019). The absolute level of differences in preference in all the researches is minimal, we assume that the specific preference in this case might be more affected by the specific job type, education or age (Rowe, Snizek 1995, Hauret, Williams 2017). On the other hand, professional challenge is significantly more pronounced by males, what might be perceived as a support to the male-warrior hypothesis (McDonald, Navarrete, Van Vugt 2012).

As regards the quality of interpersonal relations and social support, a wide consensus prevails in literature, notably that women attribute consistently higher importance to this field (Elizur 1994, Buelens and Van den Broeck 2007, Lorincová et al. 2019), what is in line in our findings. This tendency is even more accentuated when it comes to the importance of the quality of the physical working environment, our results correspond to other authors (Lorincová et al. 2019, Elizur 1994).

\section{Gender differences in the preference of cooperative and competitive behaviour}

According to our research, the most important difference between genders, consists in the preference of cooperative vs. competitive behaviour. Our findings (table 3) showed that men are clearly much more propelled by the competitive settings; while women tend to be more motivated when cooperative aspects are involved, what corresponds to the literature which is again very consistent on this matter (Vugt, Cremer, Janssen 2007, Niederle, Vesterlund 2007, Sutter, Rützler 2010).

We also tested the preference of the work settings, defined by the matrix of four quadrants high, low competition vs. cooperation (table 6); where a distinct majority of males prefer quadrant with "high competition and low cooperation"; and females, vis-versa, manifest clear preference of the setting with "high cooperation and low competition", what corresponds to the findings of Niederle and Vesterlund (2007).

\section{Conclusion}

In this paper, the main objective was to understand the gender differences in preference of motivational drivers and the nature of the gender-neutral motivational drivers. Special interest was devoted to the motivation by the competitive and cooperative organizational setting.

Our findings are as follows. Motivational drivers, significantly more preferred by males were: motivation by competition, professional challenge and development opportunities (however, here, the gender-based difference in preference was miniscule). Motivational drivers significantly highly ranked by females were: social support, physical working environment, motivation by cooperative organizational settings. Preference of financial reward and recognition of performance showed no gender differences.

The most pronounced inter-gender difference was in the preference of cooperative vs. competitive settings. That's why we extended the analysis to the matrix of four quadrants (cooperative vs. competitive, high, low). Difference 


\section{ENTREPRENEURSHIP AND SUSTAINABILITY ISSUES}

ISSN 2345-0282 (online) http://jssidoi.org/jesi/ 2021 Volume 9 Number 1 (September) http://doi.org/10.9770/jesi.2021.9.1(2)

in gender distribution was statistically significant; males are more attracted by the "high competition and low cooperation" and females vice-versa. Interestingly, quadrants "high cooperation and high competition" and "low cooperation and low competition" showed no significant difference in gender preference.

Further, we were interested in the underlying aspect of gender-neutral motivational factors (financial reward, recognition). Interestingly, both drivers were positively related with personal development for both genders. However, analysis showed, that recognition for work associates positively with competition and negatively with cooperation for males; and not for males. So, we assume the psychological processes underlying the motivational process in both genders might differ, even if both genders rank the importance of the recognition for work similarly.

On the other hand, we did not find gender differences as concerns financial reward what accentuates the need of equal pay and equal treatment for both genders.

We can conclude followingly. The literature on the gender preference of the motivational drivers is not consistent. When it comes to importance of motivational drivers at workplace, the difference might be caused by the jobtype, age, education, socio-demographic background and certainly by the cultural country-specific environment, etc. However, the general findings support the thesis that gender does constitute a predictor of preference of motivational drivers at workplace; this might hold even for the drivers where there is no apparent significant difference in the preference by gender.

The most important implication, though, is surely the argument supporting the imperative of equal pay and equal gender treatment in the frame of rewards, as proposed by the current European Union policies in the matter.

The above-mentioned findings might have important implications for HR management, especially in the field of e-commerce and e-business employees, aiming to create a gender-efficient motivational system and establish effective talent management. Similarly, the confirmation of the significant gender difference concerning the preference of competitive and cooperative behaviour should be reflected in the organizational and leadership decisions for the sake of building the organizational efficiency.

In further research it would by worthy to scrutinize a wider spectrum of motivational drivers, as well as their mutual interconnection, with the aim to understand the complexity of mental processes underlying the work motivation. Another promising research approach should be based on the analysis of relationship between motivational drivers and personality traits, what might bring more interesting insights into the psychological processes shaping the motivation of individuals. Besides the focus on the employees in the field of e-commerce and e-business, it would be interesting to widen the research focus on other specific business environments.

\section{References}

Alarcón, G., Cservenka, A., Nagel, B. J. (2017): Adolescent neural response to reward is related to participant sex and task motivation, In: Brain and cognition, 111, 51-62. DOI: https://doi.org/10.1016/j.bandc.2016.10.003

Arnania-Kepuladze, T. (2010): Gender stereotypes and gender feature of job motivation: differences or similarity, In: Problems and Perspectives in Management, 8(2), 84-93. Retrieved September 9, 2020 from https://irbis-nbuv.gov.ua

Bernard, L. C., Walsh, R. P., Mills, M. (2005): The motivation analysis test: An historical and contemporary evaluation, In: Psychological reports, 96(2), 464-492. DOI: https://doi.org/10.2466/pr0.96.2.464-492

Buelens, M., Van den Broeck, H. (2007): An analysis of differences in work motivation between public and private sector organizations, In: Public administration review, 67(1), 65-74. DOI: https://doi.org/10.1111/j.1540-6210.2006.00697.x 


\section{ENTREPRENEURSHIP AND SUSTAINABILITY ISSUES}

ISSN 2345-0282 (online) http://jssidoi.org/jesi/ 2021 Volume 9 Number 1 (September) http://doi.org/10.9770/jesi.2021.9.1(2)

Cut-e Czech s. r. o. (2015): Questionnaires. Retrieved August 10, 2018 from https://cut-e.cz

Cut-e GmbH. (2008): Adalloc: adaptive allocation of consent. Retrieved August 10, 2018 from https://cut-e.cz

Elizur, D. (1994): Gender and work values: A comparative analysis, In: The Journal of Social Psychology, 134(2), 201-212. DOI: https://doi.org/10.1080/00224545.1994.9711383

Elliot, A. J., Covington, M. V. (2001): Approach and avoidance motivation, In: Educational Psychology Review, 13(2), 73-92. DOI: https://doi.org/10.1023/A:1009009018235

Eskildsen, J. K., Kristensen, K., Westlund, A. H. (2004): Work motivation and job satisfaction in the Nordic countries, In: Employee relations, 26(2), 122-136. https://doi.org/10.1108/01425450410511043

European Commission. (2018): Equal pay. Policies. Justice and Fundamental Rights. Gender Equality. Retrieved September 20, 2020 from https://ec.europa.eu

Forgionne, G. A., Peeters, V. E. (1982): Differences in job motivation and satisfaction among female and male managers, In: Human Relations, 35(2), 101-118. DOI: https://doi.org/10.1177/001872678203500202

Furnham, A., Petrides, K. V., Tsaousis, I., Pappas, K., Garrod, D. (2005): A cross-cultural investigation into the relationships between personality traits and work values, In: The Journal of Psychology, 139(1), 5-32. DOI: https://doi.org/10.3200/JRLP.139.1.5-32

García-Bernal, J., Gargallo-Castel, A., Marzo-Navarro, M., Rivera-Torres, P. (2005): Job satisfaction: empirical evidence of gender differences, In: Women in Management Review, 20(4), 279-288. DOI: https://doi.org/10.1108/09649420510599098

Gneezy, U., Niederle, M., Rustichini, A. (2003): Performance in competitive environments: Gender differences, In: The quarterly journal of economics, 118(3), 1049-1074. DOI: https://doi.org/10.1162/00335530360698496

Gunkel, M., Lusk, E. J., Wolff, B., Li, F. (2007): Gender-specific effects at work: an empirical study of four countries, In: Gender, Work and Organization, 14(1), 56-79. DOI: https://doi.org/10.1111/j.1468-0432.2007.00332.x

Hofstede, G. (2001): Culture's consequences: Comparing values, behaviours, institutions and organizations across nations. Sage publications. DOI: https://doi.org/10.1016/S0005-7967(02)00184-5

Judge, T. A., Ferris, G. R. (1993): Social context of performance evaluation decisions, In: Academy of management journal, 36(1), 80-105. DOI: https://doi.org/10.2307/256513

Kampkötter, P. (2017): Performance appraisals and job satisfaction, In: The International Journal of Human Resource Management, 28(5), 750-774. DOI: https://doi.org/10.1080/09585192.2015.1109538

Kaufman, D., Fetters, M. L. (1980): Work motivation and job values among professional men and women: A new accounting, In: Journal of Vocational Behavior, 17(3), 251-262. https://doi.org/10.1016/0001-8791(80)90021-4

Knight, C., Haslam, S. A. (2010): The relative merits of lean, enriched, and empowered offices: An experimental examination of the impact of workspace management strategies on well-being and productivity, In: Journal of Experimental Psychology: Applied, 16(2), 158. DOI: https://doi.org/10.1037/a0019292

Knight, G. P., Chao, C. C. (1989): Gender differences in the cooperative, competitive, and individualistic social values of children, In: Motivation and emotion, 13(2), 125-141. DOI: https://doi.org/10.1007/BF00992958

Kovach, K. A. (1987): What motivates employees? Workers and supervisors give different answers, In: Business Horizons, 30(5), 58-65. Retrieved October 2, 2020 from http://homepages.se.edu/

Lee, W., Reeve, J., Xue, Y., Xiong, J. (2012): Neural differences between intrinsic reasons for doing versus extrinsic reasons for doing: An fMRI study, In: Neuroscience Research, 73(1), 68-72. DOI: https://10.1016/j.neures.2012.02.010 


\section{ENTREPRENEURSHIP AND SUSTAINABILITY ISSUES}

ISSN 2345-0282 (online) http://jssidoi.org/jesi/ 2021 Volume 9 Number 1 (September) http://doi.org/10.9770/jesi.2021.9.1(2)

Lorincová, S., Štarchoň, P., Weberová, D., Hitka, M., Lipoldová, M. (2019): Employee motivation as a tool to achieve sustainability of business processes. Sustainability, 11(13), 3509. DOI: https://doi.org/10.3390/su11133509

Major, B., Konar, E. (1984): An investigation of sex differences in pay expectations and their possible causes, In: Academy of Management Journal, 27(4), 777-792. DOI: https://doi.org/10.2307/255878

McDonald, M. M., Navarrete, C. D., Van Vugt, M. (2012): Evolution and the psychology of intergroup conflict: The male warrior hypothesis, In: Philosophical Transactions of the Royal Society B: Biological Sciences, 367(1589), 670-679. DOI: https://doi.org/10.1098/rstb.2011.0301

Niederle, M., Vesterlund, L. (2007): Do women shy away from competition? Do men compete too much?, In: The Quarterly Journal of Economics, 122(3), 1067-1101. DOI: https://doi.org/10.1162/qjec.122.3.1067

Pardee, R. L. (1990): Motivation Theories of Maslow, Herzberg, McGregor and McClelland, A Literature Review of Selected Theories Dealing with Job Satisfaction and Motivation. DOI: Retrieved September 20, 2020 from https://www.semanticscholar.org/

Rodger, S., Murray, H. G., Cummings, A. L. (2007): Gender differences in cooperative learning with university students, In: Alberta Journal of Educational Research, 53(2). Retrieved September 19, 2020 from https://eric.ed.gov/

Rowe, R., Snizek, W. E. (1995): Gender differences in work values: Perpetuating the myth, In: Work and Occupations, 22(2), 215-229. DOI: https://doi.org/10.1177/0730888495022002005

Sargent, L. D., Terry, D. J. (2000): The moderating role of social support in Karasek's job strain model, In: Work and Stress, 14(3), 245261. DOI: https://doi.org/10.1080/02678370010025568

Seiler, S., Lent, B., Pinkowska, M., Pinazza, M. (2012): An integrated model of factors influencing project managers' motivation - Findings from a Swiss Survey, In: International Journal of Project Management, 30(1), 60-72. DOI: https://doi.org/10.1016/j.ijproman.2011.03.002

Selvarajan, T. T., Cloninger, P. A. (2012): Can performance appraisals motivate employees to improve performance? A Mexican study, In: The International Journal of Human Resource Management, 23(15), 3063-3084. DOI: https://doi.org/10.1080/09585192.2011.637069

Smith, B., Tolbert, C. M. (2018): Financial motivations and small business longevity: The effects of gender and race, In: Journal of Developmental Entrepreneurship, 23(04), 1850024. DOI: https://doi.org/10.1142/S1084946718500243

Sutter, M., Rützler, D. (2010): Gender differences in competition emerge early in life. Retrieved September 9, 2020 from http://ftp.iza.org/

Takeuchi, H., Taki, Y., Nouchi, R., Sekiguchi, A., Kotozaki, Y., Miyauchi, C. M., Kunitoki, K. (2014): Regional gray matter density is associated with achievement motivation: evidence from voxel-based morphometry, In: Brain Structure and Function, 219(1), 71-83. DOI: https://doi.org/10.1007/s00429-012-0485-3

Van Yperen, N. W., Hagedoorn, M. (2003): Do high job demands increase intrinsic motivation or fatigue or both? The role of job control and job social support, In: Academy of Management Journal, 46(3), 339-348. DOI: https://doi.org/10.2307/30040627

Vischer, J. C. (2007): The effects of the physical environment on job performance: towards a theoretical model of workspace stress, In: Stress and health: Journal of the International Society for the Investigation of Stress, 23(3), 175-184. DOI: https://doi.org/10.1002/smi.1134

Vugt, M. V., Cremer, D. D., Janssen, D. P. (2007): Gender differences in cooperation and competition: The male-warrior hypothesis, In: Psychological science, 18(1), 19-23. DOI: https://doi.org/10.1111/j.1467-9280.2007.01842.x

Yamauchi, H., Lynn, R., Rendell, I. (1994): Gender differences in work motivations and attitudes in Japan and Northern Ireland, In: Psychologia: An International Journal of Psychology in the Orient. Retrieved September 10, 2020 from https://psycnet.apa.org/

Žiaran, P., Janiš, V., Pánková, B. (2016): Understanding the nature of the motivational driver "professional challenge”-a way towards higher efficiency in personnel selection, In: Proceedings of the 9th International Conference European Entrepreneurship Forum 2015: Efficiency in the Private and the Public Sector. DOI: https://doi.org/10.33844/ijol.2017.60361 


\section{ENTREPRENEURSHIP AND SUSTAINABILITY ISSUES}

ISSN 2345-0282 (online) http://jssidoi.org/jesi/ 2021 Volume 9 Number 1 (September) http://doi.org/10.9770/jesi.2021.9.1(2)

\section{Acknowledgements}

This article is one of the partial outputs under the scientific research grant VEGA 1/0694/20 - Relational marketing research - the perception of e-commerce aspects and its impact on purchasing behaviour and consumer preferences and VEGA 1/0609/19 - Research on the development of electronic and mobile commerce in the aspect of the impact of modern technologies and mobile communication platforms on consumer behaviour and consumer preferences.

Pavel ZIARAN works as a researcher at the Faculty of Management, University of Prešov, Slovak Republic. His research interests concern psychology in organizations, psychology of motivations and application of neurosciences in the field of marketing and management. ORCID ID: https://orcid.org/0000-0001-8282-9012

Richard FEDORKO has been working as a lecturer at the Department of Marketing and International Trade of the University of Prešov since 2014. In his research activities he is focusing on the issues of online marketing and e-commerce, especially on the fields of online advertising, online reputation, social media, customer support, consumer behaviour and mobile marketing.

ORCID ID: https://orcid.org/0000-0003-3520-1921

Beata GAVUROVA (corresponding author) is an expert in finance, financial analysis and financial risk management. She focuses in her research work on issues of measurement and performance management in various sectors, process management and process optimization, strategic and performance benchmarking. Her dominant research area is the development and testing in the management and performance measurement, the evaluation of methodologies and the preparation of an application platform for innovative management and performance measurement with the support of ICT. She led several national projects, has participated in many international projects targeting the innovative applications of ICT in the private and public sector.

ORCID ID: https://orcid.org/0000-0002-0606-879X

Radovan BACIK has been working as a lecturer at the Department of Marketing and International Trade of the University of Prešov since 2009. In his research activities he is focusing on the issues of Public relations, Public relations in tourism, marketing of selected areas, strategic marketing, presentation of management and marketing, communication in management, branding and innovation and online marketing.

ORCID ID: https://orcid.org/0000-0002-5780-3838

Make your research more visible, join the Twitter account of ENTREPRENEURSHIP AND SUSTAINABILITY ISSUES: @Entrepr69728810

Copyright (C) 2021 by author(s) and VsI Entrepreneurship and Sustainability Center This work is licensed under the Creative Commons Attribution International License (CC BY). http://creativecommons.org/licenses/by/4.0/ 